\title{
CORRIGENDA
}

\section{Rumen digestion and urinary excretion of purine derivatives in response to urea supplementation of sodium-treated straw fed to sheep}

\author{
BY J. BALCELLS, J. A. GUADA, C. CASTRILLO AND J. GASA
}

Vol. 69 (1993), no. 3

Page 729, Table 4

Please replace Table 4 with Table below

Table 4. Microbial $N$ supply to the duodenum estimated from the urinary excretion of allantoin expressed as absolute amount $(\mathrm{g} / \mathrm{d})$ or in relation to the intake of organic matter apparently digested in the whole tract $(\mathrm{g} / \mathrm{kg} D O M I)$ or in the rumen $(\mathrm{g} / \mathrm{kg} R D O M I)$ of sheep as assessed from the in sacco dry matter effective degradability

(Mean values for five sheep)

\begin{tabular}{|c|c|c|c|c|c|c|c|c|}
\hline \multirow{2}{*}{$\begin{array}{l}\text { Level of urea-N } \\
\text { supplementary }(\mathrm{g} / \mathrm{d}) \ldots\end{array}$} & \multirow[b]{2}{*}{0} & \multirow[b]{2}{*}{3} & \multirow[b]{2}{*}{6} & \multirow[b]{2}{*}{9} & \multirow[b]{2}{*}{12} & \multirow[b]{2}{*}{ SEM } & \multicolumn{2}{|c|}{$\begin{array}{c}\text { Statistical } \\
\text { significance of } \\
\text { treatment effects }\end{array}$} \\
\hline & & & & & & & Lin & Quad \\
\hline \multicolumn{9}{|l|}{ Microbial N: } \\
\hline $\mathrm{g} / \mathrm{d}$ & 3.55 & 5.67 & 7.92 & $7 \cdot 85$ & $9 \cdot 68$ & 0.540 & $* * *$ & NS \\
\hline g/kg DOMI & $11 \cdot 9$ & 13.5 & $15 \cdot 9$ & $15 \cdot 6$ & $19 \cdot 6$ & 1.05 & * & NS \\
\hline g/kg RDOMI & $12 \cdot 8$ & $16 \cdot 9$ & $18 \cdot 2$ & $17 \cdot 4$ & $23 \cdot 3$ & $1 \cdot 22$ & * & NS \\
\hline
\end{tabular}

Lin, Quad, linear and quadratic effects of urea-N supplementation respectively; DOMI, digestible organic matter intake; RDOMI, rumen DOMI; NS, not significant.

${ }^{*} P<0.05, * * P<0.01,{ }^{* * *} P<0.001$. 


\title{
The energy and nutrient intakes of different types of vegetarian: a case for supplements?
}

\author{
BY ALIZON DRAPER, JANET LEWIS, NINA MALHOTRA \\ AND THE LATE ERICA WHEELER
}

Vol. 69 (1993), no. 1

Page 12, Table 6

This paper stated that fibre was non-starch polysaccharides (NSP), but all values were in fact obtained by the Southgate (1978) method of analysis. As such, these values should not be compared with the Department of Health (1991) dietary reference value for NSP. Where the term 'NSP' appears in the text and tables it should be amended to read 'fibre', and the data in Table 6 should be amended as follows:

$\begin{array}{llllllllll}\text { For } & \text { NSP (g) } & 18 & 18 & 194 & 167 & 189 & 183 & 244 & 200 \\ \text { Read } & \text { Fibre (g) } & 30 \| & 30 \| & 117 & 100 & 113 & 110 & 147 & 120\end{array}$

and add the following footnote:

$$
\text { \| James, W. P. T. (1983). }
$$

Department of Health (1991). Dietary Reference Values for Food Energy and Nutrients for the United Kingdom. Report on Health and Social Subjects, no. 41. London: H.M. Stationary Office.

James, W. P. T. (1983). A Discussion Paper on Proposals for Nutritional Guidelines for Health Education in Britain. London: Health Education Council.

Southgate, D. A. T. (1978). Dietary fibre: analysis and food sources. American Journal of Clinical Nutrition 31, 107-111. 